\title{
Drivers of urban sprawl in two large Middle-eastern countries: literature on Iran and Egypt
}

\author{
Houshmand E. Masoumi*a ${ }^{\mathrm{a}}$, Maryamsadat Hosseini ${ }^{\mathrm{b}}$, \\ Amr Ah. Gouda ${ }^{c}$ \\ a Technische Universität Berlin, Germany \\ b Rutgers University NJ, USA \\ c Technische Universität Berlin, Germany; Ain Shams University, Cairo, Egypt
}

This paper reviews the relevant literature of Iran and Egypt as two large countries of the region and concludes that four phenomena are common between the two countries and are accountable for sprawling, namely (1) wholesale land selling to the lower economic class, (2) deficiencies of planning systems in controlling development plans, (3) fast and uncontrolled increase in urban population, and (4) rural-urban migration. These drivers are categorized in two classes of demographic and planning-related trends. Besides, there is a number of peculiar trends that have nationwide causes but are uncommon in Iran and Egypt. The authors of this paper consider that the demographic drivers or sprawl addressed by the Middle Eastern scholars are not actual causes but only consequences, or there is a correlation between the demographic factors and sprawl. More in-depth historical and socioeconomic studies are needed to find the associations between sprawl and unstudied phenomena like change in technologies, culture, and lifestyle.

Key Words: Urban sprawl, urban development pattern, land use planning, urban form, Middle East.

Article Info: Received: August 28, 2017; Revised: January 15, 2018; Accepted: February13, 2018; Online: May 25,2018.

\section{Introduction}

The existing literature on the basics of Middle Eastern urban sprawl has recently received the attention of scholars. Now it is obvious that urban growth

* Corresponding author:

Address: Center for Technology and Society, Technische Universität, Hardenbergstr. 1618, Berlin 10623, Germany.

Phone: (08) 82012119 | Email: masoumi@ztg.tu-berlin.de

(C)2018 Human Geographies; The authors

(c) (7) This work is licensed under a

Creative Commons Attribution 4.0 International License. DOI:10.5719/hgeo.2018.121.4 
of several cities in Iran (Masoumi, 2012, 2014) and Egypt as two large countries of the region is not natural and is considered to be a de facto based on qualitative research. Examples of recent studies confirming the above are Masoumi (2012, 2014) for Iran and Shalaby (2012), Shalaby et al. (2012), and Taubenböck et al. (2009) for Egypt. Moreover, the negative impacts of urban sprawl have been thoroughly investigated in both developed and developing countries contexts. As a part of the developing and emerging world, the Middle East has been the subject of recent studies targeting the effects of sprawl on land consumption, environmental pollutions, energy use, traffic congestion, water management, and the like.

Nevertheless, a few studies clarify why the Middle Eastern cities started to sprawl since the mid-twentieth century and why this pattern continued and worsened. Is it that social aspects, new lifestyles and/or geographical conditions were behind sprawl or more controllable causes were influential? The existing literature does not give decision makers a clear image of the situation. Thus it is not easy to learn from the past half-century so that the future generations enjoy a better quality of life in urban settlements of the region. Without identifying our past shortcomings and mistakes in planning and administration, it would be impossible to improve future cities.

The existing knowledge concerning sprawl, in particular those focusing on sprawl causes, mainly come from highly industrial or western states, while the Middle Eastern scholars' works have been limited to monitoring sprawl and assessing its impacts. As a consequence of being from different cultures, geographies, mentalities, economics, etc., the planners and decision makers of the region cannot rely on the knowledge coming from other contexts without adaptation considerations. For selecting the best planning procedures for the future, the inefficiencies or problems in different sectors like planning, demographics management, urban sociology, economics, etc. need to be investigated and defined.

In our attempt to identify the leading causes of sprawl in Iran, different types of societal, spatial, and economic issues have been studied in references in different languages. Apparently, most of the phenomena like attempts for modernisation of the country, jump in the country's revenues in the 1970 s, importing automation technologies in the middle of the twentieth century, and the related societal changes caused by modernisation work together, and it is not possible to detach them from one another. Nevertheless, in an effort to find the drivers of urban sprawl in Iran, four categories may be identified, including social drivers such as increasing rate of urban population due to the high birthrate in the early years of the Islamic revolution; migration from the rural areas to the cities due to a number of reasons like lack of facilities and public amenities in the rural areas; employment opportunities in cities, which attracts rural residents in hope of having a better life, education, etc.; and finally, the effects of modernism and post modernism in the people's choice of place. The economic drivers include issues like the low price of farmlands and lands on the peripheral areas of the metropolitan cities, low commuting cost (with the government subsidising the construction of new roads in the urban fringe and rural areas) and also the low price of fuel, the influence of land speculators on the land market. Political/administrative drivers include poorly constructed 
master plans (which encourage the urban sprawl by annexation of land from rural areas and farmlands to the city like selling unlimited land on the periphery of cities after the 1979 revolution to people to build their own houses, instead of employing infill strategies or vertical growth), weak control on urban development plans, weak control on illegal constructions on the pre-urban areas such as what the so-called "urban village", problematic land development legislation. Finally, the most important driver related to natural and environmental issues is the geographical position of the city (whether it is close to any metropolitan areas, or any economic core of the country or the natural barriers, which can limit the urban growth of some cities). Each of the mentioned factors will be explained later, and their importance and role will be discussed.

By acknowledging the complexity of the phenomenon, one must accept that multiple drivers contribute to sprawling in Egypt that can also be classified as social, economic, political drivers. These drivers within these three classifications inextricably intertwine to create the current optimum context for sprawling. Running through the genesis and evolution of each type allows us to uncover these drivers and their impact alongside with sprawling dynamics. What is interesting about sprawling in Egypt is that political drivers have significant weight in both formal and informal sprawl in Egypt, e.g. laws or decrees that were enacted regarding some past conditions (currently elapsed) but left decades in action, or extreme planning orientations to prevent possible future malaises based on the current urban realism.

In order to be able to carry out a precise analysis, one should first have an accurate definition of urban sprawl and a coherent understanding of this complex process. Yet, finding a common definition for this phenomenon is not as easy as it seems to be. In papers addressing the issue of urban sprawl, the lack of a standard definition for this phenomenon is striking. Looking at different papers in this area, despite the considerable literature, it seems that authors chose or presented their version of "urban sprawl" according to their own background and approach, and this for sure has greatly affected the definition. Opinions on sprawl held by researchers, policy makers and urban planners differ sharply, and these differences complicate the process of finding a common definition. This fact was pointed out in many papers. Harvey and Clark (1965) noted that urban sprawl is often discussed without any associated definition at all. Looking at the literature on this subject, it has been mentioned that "urban sprawl means different things to different people" (Brueckner, 2000) and that "many would claim to know it when seeing it" (Bhatta, 2010).

With regard to the discussions about the definition of urban sprawl, it is clear that depending on the different geographical, social and economic circumstances; urban sprawl can have different shapes and thus, different definitions. In terms of measuring urban sprawl, different attributes of urban form were utilised. Song and Knaap (2004) used five characteristics to measure sprawl based on the urban form of neighbourhoods; they include street design and circulation system, density, land use mix, accessibility, and pedestrian access. (Galster et al., 2001) linked sprawl to achieving low values in one dimension or more out of eight: "density, continuity, concentration, clustering, centrality, nuclearity, mixed uses, and proximity". Based on a recent study, "there is no obvious answer on how to differentiate sprawl, estimate the extent of sprawl or 
estimate the policy impact. The existing methods for quantifying informal urban sprawl are fundamentally submitted within the context of advanced Western countries. So those methods are not precisely developed for understanding the spatial attributes and unique mechanism of informal urban sprawl within Cairo region as a capital of a developing country" (Osman et al. 2016). The need for localised knowledge of sprawl exists not only about quantified measurements but also about definitions and concepts. According to what was reviewed for this study; we employ a definition already generated by observing Iranian cities (Masoumi, 2012): "Urban Sprawl is a planned or unplanned automobileoriented urban growth with lack of local public facilities and uses, public social open spaces, and relatively low population density."

In addition to the definition, the sprawl scale should also be determined before reviewing the literature. Small and medium-scale investigations are mostly found in the North American studies, where, e.g. commercial strips and drive-thru lots are discussed, while the scale of European studies is larger. The approach of the European studies to sprawl is exemplified by the report of the European Environment Agency (2006) that examines urban sprawl in several urban agglomerations and cities in the continent with a very large scale from city level to region and the continent. Such approach cannot lead to examining the micro-scale change in urban form and land use. Dispersal of urban settlements by means of geographical analysis tools is applied more in both Europe and the developing world. Since micro and small-scale examination of sprawl are less studied in the MENA region and as a result, tiny body of literature has been produced; this paper cannot review the findings in neighbourhood and district scale. Instead, city and region-scale is the basis of the analyses.

This paper tries to explore the common drivers of sprawl in Iran and Egypt. It is assumed that such causes can also stimulate sprawl in other countries of the region. Nevertheless, uncommon drivers are also identified and briefly explained based on the existing resisting literature. As a review paper, this manuscript depicts the causes that the Iranian and Egyptian scholars have identified as the sprawl drivers. The authors have almost no interference until the discussion section; they only address the local literature and classify them into categories of common and uncommon factors and also categories of planning and common demographic causes. Under the discussion section, a more critical aspect of the literature is introduced and argued that the Middle Eastern scholars have sometimes given false addresses in examining the real causes.

This article collects factors that have drawn the attention of Iranian and Egyptian researchers, but as it is explained in the discussion section, the circumstances of emergence of these supporting factors of sprawl need more in-depth original work that includes historical and socioeconomic observations.

In the below sections, the hypotheses and methods of research are briefly explained. Then the research findings are presented in two parts: (1) the common sprawl drivers of Egypt and Iran, (2) the peculiar and uncommon drivers that are found in one case-study country but not in the other one. The ending section is discussion and conclusion that summarised the results and has a partial look at the differences observed between sprawl drivers in MENA and the high-income western countries. 


\section{Methodology}

The present paper takes a descriptive approach to explain the main drivers of urban sprawl in two major countries of the Middle East, using library work on English, Persian, and Arabic literature. The diversity of sources enables the study to have a holistic approach to the subject. The primary objective is to bring social, economic, demographic, and planning-related phenomena under one umbrella of drivers that have led to the dispersal of the Middle Eastern cities. This will inform the Middle Eastern decision makers and planners about the phenomena that may be under their control, but due to lack of resources, political instability, inadequate management, etc. they have not been successful in controlling them during the past four or five decades. Furthermore, the paper provides them with an insight to the drivers, on which planners have little control.

This paper shows how the existing literature introduces planning and demographic phenomena as the main drivers of urban sprawl in the Middle East. Planning aspects that are discussed here include a range of plans, from local development plans like master and detailed plans to large-scale plans like economic and nation-wide strategic ones. In addition to problematic planning, dynamics of populations, exemplified by that of Cairo (Stewart et al. 2004), are assumed to have significant effect on dispersal of the cities in many settlements of the region, which per se has been caused by changes in economics, societal issues, lifestyles, cultures, etc. Magnificent cultural and societal change is mainly considered to be the result of confrontation of the Middle Eastern states with the western lifestyle.

Two large countries of the region are taken as study areas: Iran (1,648,195 sq. km.) and Egypt (1,001,449 sq. km.). Iran and Egypt were selected because both are developing countries located in the Middle East region. They show demographic commonalities with massive population increase between the 1960s and 2013. According to the World Bank data, the population of Iran has increased from 21.9 million in 1960 to 77.44 million in 2013. Egypt's population grew from around 28 million in 1960 to approximately 82 million in 2013 with a gross urban population of about 36 million in 2013. Each country has its own megacity (i.e., Cairo in Egypt and Tehran in Iran).

The primary approach of this study is to find possible notions that can be considered as the causes of sprawl, then dividing them into two categories of common drivers between Iran and Egypt and particular and peculiar causes. The former group of drivers are the main target of this study, which is very likely to be the cause sprawl in other areas of the Middle East. The latter reasons are less effective ones that have been only influential in one country, but still, they may be considered in case of other states.

\section{Middle Eastern sprawl drivers}

As explained above, this paper collects the most efficient causes of sprawl in the existing literature of Iran and Egypt and tries to find the common ones. The causes identified in the two countries include different phenomena originating 
from various aspects including socio-economic, spatial, planning, and administrative issues.

Four main reasons are identified in the literature which are common in the two countries: the policy of wholesale land selling, fast urban population increase, urban-rural migration, and weak control on illegal construction and agriculture infringements and arbitrary law enforcement. Each of these factors is described for the two countries.

\section{Policy of wholesale land selling}

Iran: One of the factors that contributed to fast and uncontrolled expansion of cities in Iran, was the wholesale land selling and land transfers by the government to different target groups, mainly the people with low or middle income and governmental employees, with the aim of providing them with the opportunity of homeownership. Various studies have collected evidence of whole land selling and land transfer through governmental organisations. According to these studies urban land laws in the post-revolution era can be regarded as one of the most influencing factors in the expansion of cities. Besides, land transfer and spatial planning policies also encouraged urban sprawl in Iran (Azizi, 2010; Kamrava, 2005).

Most of the distributed (transferred) lands were placed at the periphery of cities, and the poor provision of choosing the proper place for the newly transferred lands were such that the gardens and agricultural land were stuck in between the new vested (transferred) areas and the compact urban fabric (Poormohamadi and Jamekasra, 2011). An example of peripheral land development is seen in case of Urmia located in the northwest of Iran, $41 \%$ of whose urban growth of the period of 1989-2007 is connected to urban sprawl and horizontal growth, especially on the urban periphery (Mohammadi et al., 2012). Construction of houses and creation of residential areas led to an increase in the value of those lands and thus, encouraged some landowners to convert their agricultural lands to residential areas and so, had significantly contributed to the physical expansion of the cities and created fragmented residential patterns (Saraei, 2010). It has been stated by Mahmoudian et al. (2006) that one of the main reasons behind the unwanted, unplanned growth of Tehran is building different types of new towns (Shahrak) around the city, with the goal of promoting home ownership for the middle class. These suburban areas and satellite towns have gradually merged into Tehran and expanded it. Today, Tehran has more than 400 suburban towns, quarters, and districts, whose land are or have been sold and transferred to people by governmental organisations and cooperatives, so that they can have their house designed and constructed.

From 1981 to 1989 , the government of Iran ran a project of wholesale land selling with the aim of providing the lower-income class with the proper place for personal housing. From 1979 to 2003, 1.7 million of 5.1 million houses, which is one-third of the whole built houses were constructed on the transferred lands (Iranian Ministry of Housing and Urban Development, 2006). The ministry of housing was only able to answer $49 \%$ of the demand for land. These lands, in turn, answered 33\% of the demand for housing during the 1979-2003 
period. This implies that some of the lands were left vacant, which created leapfrog development patterns. The share of government in land supply decreased from $45 \%$ to $30 \%$ in the second and third development plans; the government was expected to stop interfering in the land market, and the public (government owned) lands prices were decided to get determined by the demand and supply of the land market. This decision created the expected inflation in the land market, which led to the increase of the price of land. In 2002, the ministry of housing employed wholesale land selling strategies in 300 cities of the country. This act aimed to provide the governmental employees with personal housing.

The application of these policies had some major problems and weak points, which were not in line with their primary objectives. Ironically, the process of land transfer, its costs and instalments were designed in a way that the lowincome families could not afford to buy a property and live within the borders of the city and thus most of them had to choose marginal dwellings. The average size of the whole transferred lands was more than the market trend, in lots of cities the supplied lands were greater than the market demand which led to the speculative activities and the share of deprived areas of these lands was much lower than the others (Iranian Ministry of Housing and Urban Development, 2006). In 1986, the government approved the dedication of 16.000 hectares of land to build the new towns. The plan was approved by the Council of the Architecture and Urban Planning in 1989. The primary goal of this plan was to accommodate the overflow of population from metropolitan areas and large cities and to give the middle class a proper choice of housing. Nevertheless, the statistics show that the goal was not achieved and it did not go along with the expectations (Darvish, 2007). $80 \%$ of the capacity of the new cities was empty in 2008, and almost the same amount of the lands in new cities were sold but not built up, and the government was still trying to convince people to buy properties in those cities. The reality was that people with higher income would purchase those lands with the speculative incentives (Yaftian, 2008).

It should be pointed out that, if the transferred lands are used according to the land use planning standards and optimal land use policies, they will not create sprawling patterns, but the problem is that, in most cases, such as the city of Yazd, there was no proper planning and provision on the future outcomes of these land policies. From 1956 to 2001 the physical area of the city of Yazd grew 15.5 times while the population increased 6.1 times. This means that the area has grown as much as $253 \%$ more than the population. A significant drop in population density of Yazd was observed during 1956 to 2001. It decreased from 89.4 persons per hectare in 1956 to 35.28 in 2001 (Masoumi, 2014). Zanganeh Shahraki and Hosseini (2009) investigated the issue of land transfer and whole land selling in the city of Yazd and concluded that almost $72 \%$ of the transferred lands during the period of 1996-2008 were for residential use and most of the lands were located at the fringe of the city.

One of the main reasons behind the urban sprawl in Yazd was the whole land selling and land transfers, either those which was decided in the urban planners and governmental organizations like adding 600 acres to the city as decided by the Housing and Urban Development Organization of Yazd in 1986 or adding 2800 hectares to the city area according to The Master Plan Amendment 1993 
(Saraei, 2007) or some governmental wholesale land selling projects, such as Mehr Housing project. This large-scale project was launched in tens of midsized and large cities and aimed to provide low-cost housing for the low-income families (The project was started in 2007 in case of Yazd). Unfortunately, the primary focus of the project was to keep the costs as low as possible without considering its future outcomes and consequences, and thus, the areas with the lowest land price were chosen. Instead of employing infill strategies and using brownfields and empty lands within the city, these areas were all located at the fringe of Yazd and were outside of the scope of municipal services (Zanganeh Shahraki et al., 2011).

Egypt: Driven by the fact that more than $94 \%$ of this land area is unpopulated, the condensed population around the river Nile, and the eroding modicum of agriculture lands, the Egyptian government inaugurated its strategy of Expanding out of the Narrow Valley in the late 1970s. Since then, 22 new desert cities were either constructed or are under construction, and yet more are being planned and proposed (e.g. New Luxor city, New Tushka). Many new cities are named after already established ones purporting that they are their natural extensions, e.g. New Cairo, New Aswan, New Sohag, New Al-Menaya, were called after Cairo, Aswan, Sohag, El-Menya. Still, in most cases a distance of around 10 to $15 \mathrm{~km}$ separates each new desert city from the closest already established agglomeration, in some cases, the distance is more than $40 \mathrm{~km}$.

Moreover, regarding accessibility, public transportation connections between new cities and their closest agglomerations is usually very weak; conditioning ownership of a private car in order to live or work there, albeit car ownership in Egypt is low especially outside the capital. The combined area of the 22 new desert cities exceeds 760,000 feddans $\left(3,200 \mathrm{~km}^{2}\right)$ - one feddan equals 1,038 acre -, in other words almost one-third of the area of the country of Lebanon. This vast size of the new cities has been criticized by a number of researchers (like Stewart, 1996). Housing in the new desert cities is usually comprised of a blend of private developers' compounds, public housing estates and individual subdivisions (Sims, 2012).

The policy of lands' wholesale peaked during the 1990s, 2000s, and unto now and is prominent in the new desert cities, the nominal land reclamation projects, which are actually residential compounds (e.g. the European village project on Cairo-Alexandria desert road and Ahmed Orabi area in Al-Ubur city, etc.), and finally the North coastal strip from El-Agami in Alexandria to ElDaba'a area in Masrsa Matrooh governorate (around $120 \mathrm{~km}$ in length) where summer houses and resorts were constructed. Some experts estimate the land sales from that period until now with couple millions of feddans and others go far beyond that.

Selling these huge tracts of lands not only opens the door widely for speculative interests but also encourages leapfrog developing style for many years to come still. Furthermore, the sold lands usually come with rigorous planning norms and building regulations imposing very low population densities, low buildings heights, low built up ratios and segregated land use distribution in contrast to the current urban situation in Egypt. These norms not only increase the construction costs (In 1991 the new cities around Cairo consumed 20\% of its annual capital spending (Dorman, 2013)), but also in terms of living expenses, 
and fails to attract the working class and a big sum of the middle class (Metwally and Abdalla, 2011). The new desert cities seem to attract the highest quantile in terms of income, that either wants to escape the overcrowded urban areas or has speculative interests.

\section{Weak control over illegal constructions, agriculture infringements, and arbitrary law enforcement}

Iran: The absence of proper spatial planning has had drastic effects on the urban system of Iran. There was no plan for the growth rate of urban population, urban hierarchy and the number of cities. Moreover, the role of cities in the social and economic development of the country was not explained (Poormohamadi and Jamekasra, 2011).

There is a huge difference between the actual state of the cities in Iran and the image of the cities that the development plans draw. These plans were mostly based on the separation of workplace and residence and also on car dependency, thus contributed to the expansion of the cities (Rahnama and Abbas Zade, 1999). A study titled "The Evaluation of Comprehensive Urban Plans in Iran" compared the degree of fulfilment achieved by the comprehensive plans in seven sample cities of Iran (Shiraz, Yazd, Arak, Rasht, Bandar Abbas, Zahedan, and Maraghe). The study shows that in all the seven cities except Yazd, most of the constructions are illegal as they are not included in the development and master plans (Farhoodi et al., 2009).

One example of the illegal construction and non-compliance with building regulations in Iran is the conversion of agricultural lands to built-up residential areas. This has happened mostly in the north of Iran, where there are highly fertile lands, and in Ardebil, Mashhad and other cities. As reported in an interview with the head of land affairs in the IRIB News, during 2006 to 2014 around 60 hectares of the agricultural lands were converted to other land uses, from which 80,000 cases were illegal and are now registered in judicial records (Islamic Republic of Iran Broadcasting News, 2014). These agricultural lands, as already explained, were placed at the periphery of the cities and conversion of these lands lead to an expansion of the city boundaries. Examination of the growth of Isfahan, Iran using Geographic Information Systems shows that agricultural lands located on the periphery of the city have had the least stability against sprawl in 50 years leading to 2006 (Soffianian et al. 2010). However, there are some cases related to desert cities that have scarce agricultural lands around them, so these lands have not been the main source of sprawling. One example is Yazd, Iran, whose urban area increased from 1843 ha to 13,802 ha between 1975 and 2009, but agricultural lands were not affected so much (Shahraki et al. 2011).

The agricultural census 2004 shows that in the northern rural areas of Tehran (Rudbar Ghasran); the recorded land area decreased from 559 hectares in 1994 to 143 hectares in 2004. Also, the total area of orchards faced a drastic decline from 6121 hectares to 682 and farmlands from 1,242 hectares to 764 hectares in the mentioned period (Rezvani, 2007).

The reasons behind this weak control can be summarised in 3 main points: 
- The financial independency of the municipalities: From 1983, the government decided to decrease its financial assistance to municipalities under the title of independence of municipalities. Municipalities thus have to find some ways to cover their costs and make revenue. This was mainly done through fines and penalties, levies on buildings and lands and engaging in income generating projects (Zanganeh Shahraki and Hosseini, 2009). One of the main sources of revenue for Municipalities is levies on buildings and lands. Here, municipalities sell lands beyond the limits of the master plans or allow the land use change of lands in contrast with the land use policies and plans, etc. for higher costs (Zanganeh Shahraki and Hosseini, 2009). Land use change and density increase can be considered as a sub-phenomenon of this process. This is where the municipalities sell the increased density or air rights for buildings to be higher than what the land use plans allow. $40 \%$ of the revenue of the municipalities of large cities and around $25 \%$ of total revenue in small cities comes from this source (Tajbakhsh, 2003).

- The weakness of the ratified laws and regulations: Urban laws and codes suffer from two major flaws, inefficiency and inconsistency. Some of these codes were ratified during the time when cities were not as big as today's metropolitan areas, so their social and economic conditions, as well as urban fabrics, were different from now. Furthermore, the laws defining the jurisdiction of different institutions in urban management are in some cases contradictory, and this has made serious conflicts between the municipalities and the Ministry of Housing and Urban Development on their legal authorities over the master plans and regional planning (Masoom, 2004; Zanganeh Shahraki and Hosseini, 2009).

- Lack of integrated urban management: In Iran, the complex legal system regarding regulation controls has caused serious problems in the integrated management of the cities. The weak autonomy of the municipalities and the issue of their dependency upon state, the complicated bureaucracy of urban management - municipal authorities and the problematic linkage between the municipalities and the Environmental Protection Organization, which in fact stems from lack of attention towards environmental issues in Iran, intensify the problems with integrated management system (Pourahmad et al., 2015; Rasoolimanesh et al., 2013; Redzuan et al., 2013). The current sprawling patterns of Iran is for sure unsustainable, which indicates the failure of the integrated plan, which takes into account the three dimensions of sustainability, i.e. environmental, social and economic aspects altogether. For example, lack of an integrated system for land use planning has brought about economic, social and legal problems for implementing the land use controls and this in turns contributed to the expansion of the cities (Tilaki et al., 2013).

Egypt: Land squatting, unauthorised construction upon agriculture lands in urban peripheries, and building permit violations have been imminent phenomena in Egypt since the 1960s, and they have been widely overlooked and rarely confronted. Multiple cases exist in the vicinity of the ring road of greater Cairo, and another prominent example is the transformation of the agriculture lands of Al-Mansourya into luxurious compounds and villas (Badawy, 2011). The impetuses behind them are numerous, some have been listed earlier and listing 
them all is beyond the scope of this paper. However, the volume, rate and perpetuation of the illegal constructions confirm that the government and the local authorities are overly emasculated in response. Perhaps one of the main reasons is the centralised nature of the Egyptian governance system, which has been conveyed from one dispensation to the next since the 1950s. Many political scientists have commented upon the Egyptian government and its performance over the last few decades and gave it multiple epithets: soft state, lame leviathan, gate-keeper, and the most expressive strong regime, weak state (Sims, 2012; Dorman, 2013).

Basically, the central government is represented by the ministries, and the local governance authorities are represented by the governorates and their affiliations of either marakiz or ahya. The rhetoric of decentralisation and empowerment of the local authorities is ubiquitously used by the government officials but hardly sought or applied. Financially, around $80 \%$ of the income of the governorates comes from the central government and the rest from local taxes and fees (Sims, 2012). Most of it goes as salaries and perks for the employees, who are many, but mostly receive very little income, especially at the lower level. Only 10-20 percent of the governorate's income can be directed towards urban projects. Thus, local authorities remain highly dependent upon the central government.

In terms of violations confrontation, the local authorities typically do document them but notably after they are finished or almost finished. Subsequently they do issue demolition decrees; thousands of them, in Alexandria governorate alone there are 27,000 illegal constructions, which have 150,000 demolition decrees (Abu-Shal, 2014). Still, on the ground, most of these decrees are unenforceable, and those that are actually carried out are minuscule and mainly target either the very brazen violations or the ramshackle buildings that threaten the safety of dwellers. Even for these two types the local authorities and the police, especially after the year 2011, may not even be capable of carrying them through owing to the strong opposition from the dwellers and owners and in many cases they needed aid from the army (El-Esawy, 2014). For the other illegal constructions, which do not fall under these two categories, there are many legal ways to bypass or neutralise these decrees. Moreover, after few years, utilities like drinking water, electricity, and natural gas are usually connected to the same unauthorized illegal constructions, legalising these violating constructions to a certain degree.

\section{Fast Urban Population Growth}

Iran: Urban population increase is stated to be one of most important factors behind urban sprawl in Iran due to high natural population growth rate, specifically in the early years of 1979 revolution as well as the increasing rate of rural to urban migration (Aliakbari, 2004; UN-Habitat, 2008; Movahed, 2004; Shahraki et al., 2012). During ten years, from 1976 to 1986, Iran experienced a sharp increase in its population growth rate. With the average growth rate of $3.9 \%$ per year (3.2\% from natural increase and $0.7 \%$ from immigration), Iran's population reached 49.44 million in 1986 (Roudi-Fahimi, 2002). 
The data derived from the World Bank gives a good understanding of the dynamics and changes of urban and rural demographics of the Iranian population. From 1960 to 1980 , the rural population of Iran was more numerouse than its urban population. In 1960, the urban population was almost half the rural, but this trend reversed itself after 1980. The urban population in 1980 was 19.32 million which was still lower than the rural population which was 19.56, but in 1981, the urban population, for the first time, exceeded the rural population (20.39 million urban and 20.04 million rural populations). The rural population had an increasing rate for ten years (1981-1991) and then, from 1992 it showed a decreasing rate and reached 21.43 million in 2013.

Urban population strictly increased from 1960 to 2013; the average slope of the urban population from 1960 to 1981 was 0.6 , while this value became 1.1 between 1981 and 2013. Considering the constant increase, it can be said that the urban population increased at a faster pace after 1980. The increase of natural population growth and urban population increase can be explained by some factors such as the increasing birth rate in the early years of revolution, improved primary health care and the immigration of refugees to Iran.

A pro-natalist approach was taken up by the new government after the revolution in 1979. In the beginning, a policy on population was not specified but this pro-natalist atmosphere, which later became more strengthened by the Iran-Iraq war, did encourage families to have more children (Abbasi-Shavazi, 2009). The government employed policies to support larger families and encourage other families to expand. These social policies include allowances and food subsidies, a separate book of ration coupons for newborn babies (RoudiFahimi, 2002). Studies show that this tendency to have more children was stronger in rural areas and small cities (Rafieian, 1994; Zanjani and Rahmani, 1989). The eight-year war between Iran and Iraq and other wars and conflicts in the neighbouring countries bring about an influx of refugee immigrants. Local people moved from the war-torn areas to cities, and the residence of foreign countries such as Afghanistan and Iraq migrated to larger cities of Iran to work. This is turn, contributed to a rapid rise in the population growth rate (Fanni, 2006; Roudi, 1999; bin Ibrahim and Sarvestani, 2009). Improved primary health care in both urban and rural areas and also the formation of health network system specifically in rural regions and villages, led to significant drop in the infant mortality rate from $11.4 \%$ in 1976 to $6.4 \%$ in 1985 (Roudi, 1999).

Egypt: Urban population increase is also one of the main drivers of urban sprawl in Egypt as in Iran, especially in its big cities (Hereher, 2012). The first population census in Egypt was made in 1848 (called the souls' count), and it estimates the population to around 4.5 million capita. The first organized official census was made in 1882, and the Egyptian population reached 6.7 million capita. Since the census of 1897, where the Egyptian population reached 9.7 million capita; a census was typically carried every ten years. Supposing that the first census of 1848 was accurate then the first recorded doubling of the Egyptian population was from 1848 to 1897, i.e. within a time interval of 50 years. Another doubling was made between 1897 and 1947 as the population reached more than 19 million capita, i.e. once more the doubling took 50 years. In the next 30 years, the population almost doubled as it reached 36.6 million in 
1976. In 2006, the population living inside Egypt was 72.8 million capita, i.e. it doubled once more in only 30 years. In 2013, the population was estimated to be around 82 million as mentioned before. In 2015, the population was 88 million capita (Central Agency for Public Mobilization and Statistics (CAPMAS)).

The annual population growth rate increased from $2.51 \%$ between 1950 and 1955 to $2.76 \%$ between 1955 and 1960. Since then, the annual population growth rate has been mainly decreasing reaching $1.63 \%$ between 2005 and 2010. This declining pattern is also expected to remain; reaching $0.69 \%$ between 2045 and 2050. Still, the Egyptian population is expected to reach more than 121 million capita by 2050 .

The percentage of the urban population to the whole population fluctuates around 43\% since 1980 unto 2014 (The World Bank, 2016). This ostensible stability can be ascribed to the peculiar definition of the term Urban which the Egyptian government adopts, as it strictly confines the term to a limited number of areas based on their class within the spatial hierarchy notwithstanding the size of population, i.e. some areas with population more than 10,000 capita are still considered rural. Such approach has confined the urban population to the same geographic entities for decades (Sims, 2012; Zohry, 2002). Indeed, if all the agglomerations encompassing 10,000 inhabitants or more were to be recognised as urban settlements, as in Iran and other countries, the percentage of the urban population would have risen drastically. However, based on the government's definition the urban population rose from around 16 million in 1976 (The World Bank, 2016) to more than 35 million in 2013.

The reasons of the population increase in general is the high fertility rates, albeit declining they still exceed the substitution rate, the improving health conditions projected in the increase of life expectancy at birth reaching 71 years in 2010 and the decline in the infant mortality reaching 23.5 infants death/1,000 live births in 2010 and expected to maintain its declining trajectory.

\section{Rural-Urban migration}

Iran: Job opportunities and better living conditions due to the high concentration of social, cultural, educational and welfare facilities in urban areas especially big cities attract the rural population. From 1976 to 2001, Iran experienced increasing rate of outward migration due to unemployment and poverty in rural areas (Fanni, 2006; Ziari, 2006).

Some of the recent studies suggest that this migration can root in the past decision and policies implemented by the previous governments. Land reform is one of these deficient strategies. According to (Lahsaeizadeh, 1987), migration of hundreds of thousands of rural villagers to cities was one of the effects of the 1962 land reforms, which was a part of the third national developmental plan. According to the mentioned land reforms, only those farmers who had some rights called Nasaq (less than $60 \%$ of the rural inhabitants), could own land. $44.5 \%$ of rural villagers, who were daily paid workers and were not entitled to any lands became unemployed and thus were pushed to move to urban areas (Lahsaeizadeh, 1987). From 1967 to 1982, there was a significant increase in the income of city residents as a result of the fourth national development plan, 
which focused on urban development urban planning for 46 cities. This attracted rural villagers to urban areas (Ziari, 2006).

Tehran and later on the city of Karaj received the largest number of migrants because of the high labour demand of Tehran. Karaj, which is located close to Tehran has become a point of attraction for the immigrants from villages and rural areas since the price of land was lower compared to Tehran. The population of Karaj increased from 14,000 in 1955 to 1,277,552 in 2001 (Iranian Statistic Centre, 2009), while the urban area increased from 125 to 26,000 hectares in the same period (Shahraki et al., 2012). Most of the rural immigrants of Tehran had to settle in the peripheral areas due to the lower costs of living, specifically the accommodation costs. The same situation applies to Sirjan city in Kerman province. Employment in the industrial sector was considered to be the most potent pull factor in attracting the rural immigrants. Dysfunctional city planning forced migrants to settle at the periphery where accommodation costs were much lower compared to the city centre (Mahmoudabadi et al., 2013).

The evidence of rural-urban migration is not limited to Tehran. Yazd province is the second most industrialized province of Iran, and the city of Yazd can be called one of the industrialised cities of the country with one of the highest rates of the concentration of industrial investments. This has made Yazd a great point of attraction for the job seekers, either from other cities of the Yazd province or other areas of the country, like Isfahan, Kerman and Tehran and rural areas. The industrial functions are known as the most important migrant attractor of the city. Statistics show that almost $50 \%$ of the population growth of Yazd is due to inward migration (Zanganeh Shahraki et al., 2011).

Egypt: After the revolution of 1952 in Egypt when Nasser took over the presidency of Egypt, he tried to veer the trajectory of the Egyptian economy from being agriculture dependent into an industrial era. Therefore, he established a number of industrial areas in Cairo, Alexandria and other cities. This, in turn, hiked the internal migration during the late 1950s and the early 1960s, as people migrated to work in the newly established factories (Zohry, 2002). During the 1970s, 1980s, and 1990s, up to 2006, the figure of internal migration remained between 4 million and 5 million. Ergo, its percentage of the whole population dropped from around $11 \%$ in 1976 to around $6.5 \%$ in 2006 (Central Agency for Public Mobilization and Statistics, 2008; Zohry, 2009). Moreover, the percentage of the rural-urban migration dropped from $24.6 \%$ in 1976 to only $13.4 \%$ in 1996. Surprisingly the percentage of the urban-rural migration increased from only $6.5 \%$ in 1976 to $22.6 \%$ in 1996, as shown in Table 1 . Based on these numbers, urban expansion and demand upon dwellings in the urban areas, which gained a fierce momentum from the rural-urban migration in the 1950 s and 1960s accompanied with the high population growth rate should accordingly be showing some signs of slowing down. However, the opposite is true; urban expansion is evident in the last 30 years and gained a big thrust after the uprising of January 2011.

Many scholars tried to justify the declining rural-urban and the rising urbanrural migration in Egypt (an anomalous trend in developing countries) by questioning the accuracy of the census data, or by saying that, the censuses do not capture the factual movements on ground. For once, the census may not be catching the rural labourers, who still have a residence in rural areas, it also may 
Table 1. Internal Migration by type, Egypt, 1976-1996 calculated for the 1976, 1986 and 1996 census data. Source:(Zohry, 2002).

\begin{tabular}{lllllll}
\hline & \multicolumn{5}{c}{ Census Year } \\
\cline { 2 - 7 } & 1976 & 1986 & 1996 \\
\hline Urban-Urban & $2577959(64.3 \%)$ & 1003054 & $(72.9 \%)$ & 2535864 & $(60.4 \%)$ \\
\hline Rural-Urban & 984469 & $(24.6 \%)$ & 540933 & $(13.1 \%)$ & 562471 & $(13.4 \%)$ \\
\hline Urban-Rural & 260295 & $(6.5 \%)$ & 422955 & $(10.3 \%)$ & 949489 & $(22.6 \%)$ \\
\hline Rural-Rural & 186724 & $(4.7 \%)$ & 152296 & $(3.7 \%)$ & 147611 & $(3.5 \%)$ \\
\hline Total & $4009447(100 \%)$ & $4119238(100 \%)$ & 4195435 & $(100 \%)$ \\
\hline
\end{tabular}

not be capturing the seasonal migration. Moreover, people in the urban areas sometimes tend to hide their rural origins. These factors surely can affect the census; however, one more reason can be liable in producing these baffling figures, especially the high figures of urban-rural migration. It is again the perplexing definition of urban in Egypt, which currently considers many areas, which are actually urban in terms of population and nature as rural areas, ergo part of the urban-rural migration is, in fact, an urban-urban migration, also part of the rural-rural migration being actually a rural-urban one.

Table 2 provides an overview to the causes of sprawl in the two countries. It has not been attempted to make a one to one relation between the drivers in the pilot countries. In other words, only the impression received from the literature has been reflected by the authors in this table. It can be imagined that some of the causes written for one country can be valid for the other in case new studies are conducted focusing on that topic in the future.

\section{Particular or Peculiar causes}

Aside from the common reasons explained in the previous part, there are some other reasons identified by researchers and specific to each country, that contribute to the horizontal expansion and dispersal of the cities. These reasons are listed below:

Some of the particular reasons of sprawl which are especially seen in Iran but not in Egypt include decrease of commuting costs, development of transportation networks (UN-Habitat, 2008; Kazemipour and Hajian, 2011; Masoumi, 2014; Mahmoudabadi, et al., 2013) low price of fuel and increasing rates of car dependency (Poormohamadi and Jamekasra, 2011; Pourahmad et al., 2007), the geographical positions of some cities such as the Karaj, Sirjan, Khomeini Shahr, which locates them at the transportation hubs or close to the megacities and metropolitan areas (UN-Habitat, 2008; Kazemipour and Hajian, 2011; Shahraki et al., 2012), the influence of land speculators on the land market (Davoudpour and Ardalan, 2009; Ahmadi, 2013), and low prices of agricultural and peripheral land. In Yazd, the price of land is directly correlated with its distance from the city centre, the farther the land is situated the lower is the price except from two luxurious districts, which are located in southeastern part of the city. Therefore, people with lower income can only afford to live in the urban fringe and commute to the city centre for work. This has resulted in the formation of unplanned suburbs, which later merged into a city and created a low-density pattern of urban development. The same situation applies to Sirjan and many 
Table 2. Overview of the causes of urban sprawl in Egypt and Iran.

\begin{tabular}{|c|c|c|}
\hline & Egypt & Iran \\
\hline $\begin{array}{c}\text { Socio- } \\
\text { Demographic } \\
\text { Drivers }\end{array}$ & $\begin{array}{l}\text { Increase in Egyptian population in } \\
\text { general and its urban population in } \\
\text { specific. } \\
\text { Rural-urban migration is one of the } \\
\text { early drivers of sprawling, which has } \\
\text { a long-term incremental influence } \\
\text { regardless of its decline over the last } \\
28 \text { years. }\end{array}$ & $\begin{array}{l}\text { Population increase (due to high birth } \\
\text { rate in the early years of the } 1979 \\
\text { revolution) as well as the increasing } \\
\text { rate of urban population. } \\
\text { Rural-urban migration (due to number } \\
\text { of reasons like lack of facilities and } \\
\text { public amenities in the rural areas, } \\
\text { work demand in the cities which } \\
\text { attracts rural people in hope to make a } \\
\text { better life, education). }\end{array}$ \\
\hline $\begin{array}{c}\text { Economic } \\
\text { Drivers }\end{array}$ & $\begin{array}{l}\text { The current fragmented and } \\
\text { diminutive agriculture landholdings } \\
\text { (expected to further disintegrate) } \\
\text { curtails owners from generating a } \\
\text { decent income from their lands and } \\
\text { pushes them to exploit their lands in } \\
\text { other uses. } \\
\text { The market value of built-up land is a } \\
\text { multifold compared to agricultural } \\
\text { land, which constitutes a strong } \\
\text { enticement for piecemeal but } \\
\text { rampant sprawling upon agriculture } \\
\text { lands. }\end{array}$ & $\begin{array}{l}\text { Low commuting cost (with the } \\
\text { government subsidizing the price of } \\
\text { fuel and the construction of new roads } \\
\text { in the urban fringe and rural areas). } \\
\text { The low price of farmlands and lands } \\
\text { on the peripheral areas of the } \\
\text { metropolitan cities encourage low- } \\
\text { income people to convert the } \\
\text { farmlands into residential areas and } \\
\text { built up at the periphery of the cities. } \\
\text { The influence of land speculators on } \\
\text { the land market. }\end{array}$ \\
\hline $\begin{array}{c}\text { Political/ } \\
\text { Management } \\
\text { Drivers }\end{array}$ & $\begin{array}{l}\text { Exemption some building uses from } \\
\text { the proscription of building on } \\
\text { agriculture lands is a loophole } \\
\text { exploited for the sake of infringing. } \\
\text { Weak governmental control on illegal } \\
\text { construction accompanied with lax } \\
\text { and arbitrary law enforcement upon } \\
\text { infringers nullifies the current } \\
\text { prescription. } \\
\text { Planning and constructing new desert } \\
\text { cities, slow growth and vacancies; } \\
\text { and notwithstanding the currently } \\
\text { vacant cities. } \\
\text { Allowing the construction sprinkled } \\
\text { and fragmented buildings and } \\
\text { compounds in the new desert cities } \\
\text { rather a condensed and phased one. } \\
\text { The prejudice that the planning } \\
\text { policies of low population densities } \\
\text { and segregated land use can forestall } \\
\text { the degradation of urban areas } \\
\text { towards informality or crowdedness } \\
\text { pushes towards the formalisation of } \\
\text { urban sprawls. } \\
\text { The lack of convenient housing } \\
\text { options; in terms of cost, } \\
\text { transportation, location, iob } \\
\text { opportunities; pushes towards further } \\
\text { sprawling on the peripheries of the } \\
\text { cities. } \\
\text { Encouraging gated communities and } \\
\text { fragmented growth through selling } \\
\text { huge tracts of lands to developers } \\
\text { and individuals. }\end{array}$ & $\begin{array}{l}\text { Poor master plans, which encourage } \\
\text { the urban sprawl by the annexation of } \\
\text { land from rural areas and farmlands to } \\
\text { the city like selling unlimited land on } \\
\text { the periphery of cities after the } 1979 \\
\text { revolution to people to build their own } \\
\text { houses instead of employing infill } \\
\text { strategies or vertical growth. } \\
\text { Weak control on illegal constructions } \\
\text { on the pre-urban areas such as so- } \\
\text { called "urban villages". } \\
\text { Weak control on urban development } \\
\text { plans. } \\
\text { Problematic land development } \\
\text { legislation. }\end{array}$ \\
\hline
\end{tabular}


other cities in Iran (Azimi, 2001; Zanganeh Shahraki and Hosseini, 2009; Mahmoudabadi et al., 2013). It is always the case that cities would expand in the direction that has less natural limitations. For example, Arak has expanded in the northern part as the southern part is mountainous thus limited but there is no natural limitation in the northern part of the city (Davoudpour and Ardalan, 2009; Zanganeh Shahraki and Hosseini, 2009).

In Egypt, the peculiar reasons, which were identified have some interconnections with the government trying to meet the increasing housing demand (Shaalan, 2013) by planning and constructing new desert cities as its sole response strategy. Roads are constructed to reach these new towns and connect them, e.g. ring road in Cairo, which in turn encourages urban sprawl (Sutton and Fahmi, 2001). Desert cities, in contrast to the typical Egyptian urban context, are designed to have low population densities and segregated land uses (Sims, 2012). Moreover, local authorities of the new cities allow sprinkled and fragmented development rather than adopting a more condensed, focused, and phase-wise trajectory. The establishment costs of the new cities are exorbitant (Dorman, 2013) making the housing projects unaffordable for workers (Sutton and Fahmi, 2001) and wide range of the Egyptian community (Hereher, 2012). On the other hand, low-income housing projects are mostly substandard, away from job opportunities and services (Hereher, 2012; Dorman, 2013), ergo they fail to attract people, who in any case are disinclined to relocate away from their families and friends.

Moreover, those who own agriculture lands, especially diminutive ones, are usually enticed by the multifold increase in their land value when converted to a building land use as their lands do not bring them decent ongoing income (Shaalan, 2013; Sims, 2012). Although such action is proscribed by law, still some legislative loopholes, e.g. exemptions which are sometimes misused, coupled by the typically lax (Parker and Coyle, 1981), and arbitrary manner of law enforcement abet other landowners to follow suit even without permission.

\section{Discussion}

This paper depicts the four most influential reasons behind sprawl in Iran and Egypt as two large nations of the Middle East. Two of the explained drivers are demographic phenomena while the other two are in relation with the planning process. The following list summarizes the mentioned causes: (1) the policy of wholesale land selling; (2) weak control on illegal construction and agriculture infringements and arbitrary law enforcement; (3) fast urban population growth; (4) rural-urban migration.

One point that should be emphasised here is that all the above-mentioned reasons work with one another, and no dominant super driver has transformed the urbanisation of the region alone. Assuming that every single cause explained in this article has established a ground for sprawl will give the reader a false understanding. The best way of investigating the reasons behind urban sprawl is to do it considering historical trends. Decades before sprawl become a crucial urban development pattern in the region, new societal and economic issues emerged, most of which were brought to the region from industrial countries or 
were the product of global circumstances. The examples are the emergence of the car in the first half of the twentieth century, globalisation and its effects of lifestyles and consumerism, familiarity of the Middle Eastern populations with the international cultures after the world wars, and the like. In other words, societal change has been the foundation of all political, demographic, and planning-related reasons discussed in this paper. Unstable political regimes and governments, deficient planning systems, rapid changes in urban and rural demographics, etc. rooted in out-of-control societal change resulted from international relations. This assumption needs separate studies with an interdisciplinary approach to international politics and the impacts on national sociology and planning. This large perspective is beyond the scope of this paper; we have only focused on nation-wide trends.

The review of literature suggests that planning shortcomings and rapid and uncontrolled demographic change have been the basis of today's sprawl in the Middle East, even though uncontrolled demographic change can be a product of bad strategic planning. The worst planning decisions leading to sprawl has been taken in the eras that radical political events were happening, like wholesale land distribution in the two countries. Such decisions have dominantly taken by authorities with weak expertise and radical political or religious ideologies, i.e. an intense sprawl started in the city of Yazd after the new revolutionary government took over in 1979 and continued to today (Masoumi, 2014). Concerning wholesale land selling, revolutionary ideology of providing land for construction of do-it-yourself houses by poor classes was the motive. This solution was to empower the lower economic class, but became a challenge for the whole urbanisation of the countries, due to lack of attention to necessary fundamental conditions.

Strong causes related to demography and planning can suffice the hypothesis of this study. The top-down Middle Eastern planning has not been able to control rapid increase of urban population in the mid-twentieth century by efficient development plans. Change in economic processes aroused migrations at the same time that lack of revitalisation plans could not provide quality of life in the historical cores. Thus, the replacement of populations occurred; the poor migrant populations took deteriorated cores or newly distributed low-serviced peripheral lands. More studies are needed to investigate how rapid economic and societal change were proceeded by bad urban planning. Political circumstances especially need to be studied, e.g. it is desirable to know in which of the case-study countries the governmental strategies and decisions have led to more sprawling. In Iran, the concentrated governmental decision-making backed by private consultation has ruled urban planning during the past decades. Like other sectors, the Egyptian urban policy has been under the effect of foreign investments before the 2011 revolution and liberalisation after it. Both countries have the experience of privatisation of governmental activities. However, the current literature fails to track the real governmental causes of urban sprawl or fast urbanisation processes, so it is hard or impossible to say if the governmental urban planning has been more effective in strengthening sprawl in Iran or Egypt. This topic may be subject to more investigations in the future to provide local examples of urban planning policy leading to sprawl or compactness. The role of societal and socio-economic change and needs have an enormous 
capacity to connect the strategies backing sprawl and zoning in both countries.

Apart from the main drivers introduced by the literature, other reasons with local impact have also been tracked in the literature, which has found to be uncommon between the two observation countries. The outcome of these reasons could have been as strong as the main causes. To summarise them, we have listed them as follows:

Iran: (1) low commuting costs; (2) development of transportation networks; (3) low price of fuel; (4) increasing rates of car dependency; (5) location of cities in the vicinity of large metropolitan areas; (6) low prices of agricultural and peripheral land; (7) special geographical location of some cities.

Egypt: (1) increasing housing demand; (2) construction of new roads; (3) policies leading to planning low population density and zoning in desert cities; (4) loopholes in policies regarding lower prices of agricultural land compared to urban land.

As seen above, development of transportation networks in Iran and construction of new roads in Egypt seem common, but because the Iranian literature address rail, bus, roads, etc. but the Egyptian studies identify only roads (like the ring road of Cairo) as a reason for sprawl, this driver has not been referred to as a common one. Examining the current literature, we cannot be sure that the above factors are different in the two countries. These differentiations can be the result of lack of evidence in the literature of one of the countries. It is likely that if similar methodologies are taken in both countries, some of the above factors become common sprawl causes.

Another outcome of this study is underlining the difference between causes of sprawl in developing versus developed countries. As in developing countries exemplified in this research, socio-political reasons are powerful motives of sprawl in the developed world. However, when examining the causes more thoroughly, dissimilarities in different countries and cultures are identified. For instance, Leipzig, Germany experienced heavy suburban construction boom in the 1990s in parallel with shrinkage of the city core (Nuissl and Rink, 2005). This development pattern was shaped as a result of the political conditions of the aftermath of the reunification of Germany.

Dramatic population loss in Leipzig happened as a general consequence of limitation of employment opportunities in eastern Germany. The city lost 100,000 inhabitants in a very short time. While the city's shrinkage had started since the 1960s but suburbanization started after the reunification and speeded up in 1992 (Rink et al., 2010). Social and economic reasons are claimed to be important drivers of urban and suburban sprawl that happened earlier in North America. Lifestyle-driven urban sprawl (Gargiulo Morelli et al., 2010) and antiurban ideology (Hadden and Barton, 1973) are among the social motives of sprawl in the United States in the first half of the twentieth century. These trends have been effective in parallel with the local and statewide spatial planning policies like zoning. (Gillham and MacLean, 2002) asserts four drivers: land ownership and use, transportation patterns, telecommunications technology, and regulations and standards. The socio-economic causes that (Bruegmann, 2005) finds are stronger; he concludes that five large factors have caused sprawl in the United States: anti-urban attitude and racism, economic factors and the capitalist system, government, technology, affluence and 
democratic institutions. Socio-economics have been more important in North America than in the Middle East, or at least more studies have been conducted on this topic.

\section{Critical Feedback to the Middle Eastern Literature}

A basic point noteworthy of explaining is that in general the local literature recently refers to the topic of this study as "urban sprawl" more dominantly rather than only rapid urban development or urbanisation process. Older studies addressed it as fast urbanisation more often at least in case of Iran. Previous studies show that there are both similarities and differences between the Middle-Eastern sprawl and the international or western sprawl (Masoumi, 2012), but this development type can be called urban or suburban sprawl. Hence, to connect the local findings to the international literature, this study names the phenomenon as urban sprawl.

As mentioned in the previous sections, the reviewed literature provides a handful of causes of sprawl, four of which can be identified as common drivers. The planning-related causes and the failures of urban development policies can certainly have an important role in strengthening sprawl. This is not limited to the Middle East, i.e. the urban development policy in the United States has been much criticised as a major cause of sprawl. This supports a type of planned sprawl that is common in several different regions of the world. Poor regionalscale policies such as the policy of wholesale land selling in the two countries have had a strong role in enhancing dispersed development patterns. The examples are planning satellite cities of about 30-40 thousand inhabitants (or even 650,000 people for the case Hashtgerd new city) in a short distance of 25$40 \mathrm{~km}$ up to $90 \mathrm{~km}$ outside of the metropolitan areas in Iran as well as locating the city of New Cairo near the edges of Cairo. According to the definition of sprawl for applying in this paper, sprawl can be planned or unplanned. Planned sprawl is considered to be unintentional in the Middle East and may have roots in the weak understanding of the governmental authorities and nation-wide decision makers about urban phenomena and concepts. It is claimed that the Middle-Eastern planned sprawl is unintentional because no sign of desire or positive approach of decision makers toward dispersed developments can be detected. In other words, during this study, no written documents or policies have been found that support urban sprawl as an acceptable or useful planning approach. Hence, this can stem from a lack of local academic literature and applied vernacular basics that clarify the negative impacts of sprawl in the region. In several countries of the region, large-scale policies are linked with the political conditions and the ruling parties.

Weak control on development plans addressed by the literature is also an understandable and logical cause. Nevertheless, when it comes to the demographic causes, holistic view that the literature gives us fails to be clear and acceptable. The scholars of the region address high rates of urban population increase and rural-urban migration as two drivers, while they may be correlated with urban sprawl rates, but there is not convincing evidence to support the causation. In fact, more complex combinations of urban planning and socioeco- 
nomic and demographic change during the recent decades may be the real reason for sprawl. This combination is closely in relation to cultural changes in the lifestyle of people together with the emergence of new mobility and communication technologies. Thus, the authors of this paper reject the demographic factors addressed by the existing literature to be independent causes of sprawl, but they can be the associated phenomena working with urban planning policies or in some cases they can be the consequences. Of course, finding all the real causes and their combinations needs original research, which is out of the scope of this review article.

\section{Conclusion}

Although urban sprawl is an existing and expanding trend in the Middle East, there are some differences between its characteristics and the specifications of the western sprawl, but the dispersal of settlements seen in the region can still be classified as sprawl (Masoumi, 2012). Nevertheless, as demonstrated in this paper, the causes of sprawl in different countries may vary. In the Middle East, problematic planning and demographics have been identified by scholars to be the most effective drivers.

This paper finds two groups of sprawl causes: planning/policy and demographics, under each there are two smaller drivers of sprawl. The authors of this article claim that the causes related to development policies and planning have much higher efficiency and are the real sprawl drivers. The population-related causes may be drivers combined with other phenomena or in some cases the consequence of sprawl rather than cause. It is argued that the researchers of the region have confused causality with correlation. More in-depth multilayered investigations are needed to clarify the historical and socioeconomic aspects of the sprawl drivers and the background of their emergence.

\section{Acknowledgements}

This paper is a summary of a working paper prepared for the website of Center for Technology and Society in Technische Universität Berlin. No funding was received to conduct this research.

\section{References}

Abbasi-Shavazi, M.J. (2009), "Recent changes and the future of fertility in Iran", in United Nations (ed.), Population Bulletin of the United Nations: Completing the fertility transition, Population bulletin of the United Nations. Special issue, United Nations, New York, N.Y., p. 389-401.

Abu-Shal, N. (2014), The Enforcement of 144 Elimination Decree and the Removal of 64 Encroachments on State Land, Al-Masry Al-Youm, 30 November 2016, https://goo.gl/4DqRyR.

Ahmadi, G. (2013), The role of speculation on the urban sprawl: An analytical model. 
Aliakbari, E. (2004), "Urban development and social pathology in Iran", Geographical Research Quarterly, vol. 48, p. 49-70.

Azimi, N. (2001), "Structural changes in the city of Tabriz", Geographical Space Magazine, vol. 4, p. 1-24.

Azizi, M.M. (2010), Urban congestion - on the principles and criteria of urban density, Tehran University Press.

Badawy, M. (2011), Al-Mansourya. The coumpound of those who sold Egypt, Alwafd.

Bhatta, B. (2010), Analysis of Urban Growth and Sprawl from Remote Sensing Data, Berlin, Heidelberg: Springer Berlin Heidelberg.

bin Ibrahim, A.L. and Sarvestani, M.S. (2009), "Urban sprawl pattern recognition using remote sensing and GIS - Case study Shiraz city, Iran", Joint Urban Remote Sensing Event, IEEE, p. 1-5.

Brueckner, J.K. (2000), "Urban Sprawl. Diagnosis and Remedies", International Regional Science Review, vol. 23, no. 2, p. 160-171.

Bruegmann, R. (2005), Sprawl: A Compact History, Chicago, The University of Chicago Press.

Central Agency for Public Mobilization and Statistics (CAPMAS), Published censuses and estimations from 1897-2015.

Central Agency for Public Mobilization and Statistics (CAPMAS) (2008), Census 2006.

Darvish, M. (2007), "The mission of the second generation of new towns", Iran daily newspaper, 30 November 2016, https://goo.gl/LwLnvb.

Davoudpour, Z. and Ardalan, D. (2009), "The investigation of effective factors on great and middle cities", Hoviate Shahr, vol. 3, p. 63-72.

Dorman, W.J. (2013), "Exclusion and Informality. The Praetorian Politics of Land Management in Cairo, Egypt", International Journal of Urban and Regional Research, vol. 37, no. 5, p. 1584-1610.

El-Esawy, M. (2014), "Cairo governorate waging a campaign to remove the illegal buildings in El-Maadi", Al-Youm Al-Sabe.

European Environment Agency (2006), "Urban sprawl in Europe, the ignored challenge", European Commission: Joint Research Center 2006, vol. 6, no. 23, p. 24-5.

Fanni, Z. (2006), "Cities and urbanization in Iran after the Islamic revolution", Cities, vol. 23, no. 6, p. 407-411.

Farhoodi, R., Gharakhlou-N, M., Ghadami, M. and Khah, M.P. (2009), "A Critique of the Prevailing Comprehensive Urban Planning Paradigm in Iran. The Need for Strategic Planning", Planning Theory, vol. 8, no. 4, p. 335-361.

Galster, G., Hanson, R., Ratcliffe, M.R., Wolman, H., Coleman, S. and Freihage, J. (2001), "Wrestling Sprawl to the Ground. Defining and measuring an elusive concept", Housing Policy Debate, vol. 12, no. 4, p. 681-717.

Gargiulo Morelli, V., Salvati, L. and Munafò, M. (2010), Ad hoc urban sprawl in the Mediterranean city: Dispersing a compact tradition?, Roma, Nuova cultura.

Gillham, O. and MacLean, A.S. (2002), The limitless city: A primer on the urban sprawl debate, Washington, D.C.: Island Press.

Hadden, J. and Barton, J. (1973), "An image that will not die. thoughts on the history of", Urban Affairs Annual Review, vol. 7, p. 79-116.

Harvey, R.O. and Clark, W.A. (1965), "The nature and economics of urban sprawl", Land Economics, vol. 41, no. 1, p. 1-9. 
Hereher, M.E. (2012), "Analysis of urban growth at Cairo, Egypt using remote sensing and GIS", Natural Science, vol. 4, no. 6, p. 355-361.

Iranian Ministry of Housing and Urban Development (2006), Urban land plan, Housing master plan.

Iranian Statistic Centre (2009), Census data.

Islamic Republic of Iran Broadcasting News (IRIB News) (2014), Dealing with illegal construction on agricultural land.

Kamrava, S.M.A. (2005), An Introduction to the Contemporary Urbanism of Iran, Tehran University Press.

Kazemipour, S. and Hajian, A. (2011), "Creation of the first metropolitan area in Tehran region- focusing on the role of immigration", Population, vol. 76, p. 21-48.

Lahsaeizadeh, A. (1987), "Land Settlement and Cooperatives (FAO)", Journal of Land Reform, vol. 1, no. 2, p. 22-57.

Mahmoudabadi, S.E., Soroushnia, R. and Zekri, A. (2013), "Evaluating Iranian Urban Development Plants in order to develop a Development Plan for Sirjan City of Iran", Technical Journal of Engineering and Applied Sciences, vol. 3, no. 19, p. 2365-2370.

Mahmoudian, A.A., Ghasemi, H., Houshmand Fini, G. and Artidar, R. (2006), A look to Tehran from start till now, Tehran, Gitashenasi Institute.

Masoom, J. (2004), "Municipalities and space management", Shahrdariha, vol. 6, no. 65 , p. 5-10.

Masoumi, H.E. (2012), "Urban sprawl in Iranian cities and its differences with the western sprawl", Spatium, no. 27, p. 12-18.

Masoumi, H.E. (2014), "Urban sprawl in mid-sized cities of MENA, evidence from Yazd and Kashan in central Iran", Management Research and Practice, vol. 6 , no. 2, p. 25-41.

Metwally, M. and Abdalla, S.S. (2011), Impact of Gated Communities on the Urban Development of New Cities in Egypt, Center for Planning and Architectural Studies (CPAS).

Mohammadi, J., Zarabi, A., \& Mobaraki, O. (2012), "Urban sprawl pattern and effective factors on them: The case of Urmia City, Iran", Journal of Urban E Regional Analysis, vol. 4, no. 1, p. 77-89.

Movahed, K. (2004), "A study on the dwindling of Shiraz green areas", Proceedings of 40th ISoCaRP congress, p. 18-22.

Nuissl, H. and Rink, D. (2005), "The 'production' of urban sprawl in eastern Germany as a phenomenon of post-socialist transformation", Cities, vol. 22, no. 2, p. 123-134.

Osman, T., Arima, T., and Divigalpitiya, P. (2016), "Measuring urban sprawl patterns in Greater Cairo Metropolitan Region", Journal of the Indian Society of Remote Sensing, vol. 44, no. 2, p. 287-295.

Parker, J.B. and Coyle, J.R. (1981), Urbanization and agricultural policy in Egypt, Foreign agricultural economic report, vol. 169, Washington, D.C., United States Department of Agriculture.

Poormohamadi, M. and Jamekasra, M. (2011), "Analysis of the pattern of uneven development in Tabriz", Geographical Research, vol. 25, no. 100, p. 31-54.

Pourahmad, A., Baghvand, A., Zangenehe Shahraki, S. and Givehchi, S. (2007), 
"The Impact of Urban Sprawl up on Air Pollution", International Journal of Environmental Research, vol. 1, no. 3, p. 252-257.

Pourahmad, A., Sedigheh, L., Omranzadeh, B. and Mahdi, A. (2015), "The failure of the integrated urban management in Iran: an analysis from the perspective of interactive and legal problems between the state and municipality", International Journal of Management Science, vol. 2, no. 1, p. 1-12.

Rafieian, M. (1994), Urban system in developing countries. Case study Iran-Esfahan, Tarbiat Modarres University Press.

Rahnama, M.R. and Abbas Zade, G.H.R. (1999), The principles, foundations and models of evaluation of Mashhad physical form, SID publications.

Rasoolimanesh, S.M., Jaafar, M. and Nurwati, N. (2013), Urban Planning and Management System in Iran. A Review and Assessment, vol. 18, no. 2, p. 220-229.

Redzuan, M.'r., Kiani, A., Sardri, F.S., Edalati, A. and Abbasi, Z. (2013), "Comparative analysis of traditional and new approach to urban management in Iran", Progress in Management Sciences, vol. 1, no. 1, p. 24-35.

Rezvani, M.R. (2007), Counter-urbanization and functional changes in northern rural areas of Tehran, Pazhohesh haye goghrafiaee [Geographical Research].

Rink, D., Haase, A., Bernt, M., Arndt, T. and Ludwig, J. (2010), Urban shrinkage in Leipzig and Halle, the Leipzig-Halle urban region, Germany, Seventh Framework Programme, European Union.

Roudi, F. (1999), "Iran's revolutionary approach to family planning", Population today, vol. 27, no. 7, p. 4-5.

Roudi-Fahimi, F. (2002), Iran's Family Planning Program: Responding to a Nation's Needs, Washington, DC: Population Reference Bureau.

Saraei, M.H. (2007), "Multi-dimensional patterns of physical development of Yazd", Geographical Research Quarterly, vol. 84.

Saraei, M.H. (2010), "Why residential transferred lands in the city of Yazd were left unused?", Urban Regional Studies and Research, vol. 1, no. 3, p. 43-70.

Shaalan, I. (2013), "Sustainable urban transformation in small cities in Egypt. A UN-habitat perspective", Journal of Cleaner Production, vol. 50, p. 200-204.

Shahraki, S.Z., Sauri, D., Serra, P., Modugno, S., Seifolddini, F. and Pourahmad, A. (2011), "Urban sprawl pattern and land-use change detection in Yazd, Iran", Habitat International, vol. 35, no. 4, p. 521-528.

Shahraki, S.Z., Seifolddini, F. and Pourahmad, A. (2012), "Urban Sprawl and Fertile Agricultural Lands in Iranian Cities - Case Study: Tehran and Karaj", Journal of Civil Engineering E Architecture, vol. 6, no. 2, p. 204-2010.

Shalaby, A. (2012), "Assessment of Urban Sprawl Impact on the Agricultural Land in the Nile Delta of Egypt Using Remote Sensing and Digital Soil Map", International Journal of Environmental Sciences, vol. 1, no. 4, p. 253-262.

Shalaby, A.A., Ali, R.R. and Gad, A. (2012), "Urban sprawl impact assessment on the agricultural land in Egypt using remote sensing and GIS. A case study, Qalubiya Governorate", Journal of Land Use Science, vol. 7, no. 3, pp. 261-273.

Sims, D. (2012), Understanding Cairo: The logic of a city out of control, 1st paperback ed., Cairo, New York: The American University in Cairo Press.

Soffianian, A., Nadoushan, M. A., Yaghmaei, L. and Falahatkar, S. (2010), "Mapping and analyzing urban expansion using remotely sensed imagery in Isfahan, Iran", World Applied Sciences Journal, vol. 9, no. 12, p. 1370-1378.

Song, Y. and Knaap, G.J. (2004), "Measuring urban form. Is Portland winning 
the war on sprawl?", Journal of the American Planning Association, vol. 70, no. 2, p. 210-225.

Stewart, D.J. (1996), "Cities in the desert: the Egyptian new-town program", Annals of the Association of American Geographers, vol. 86, no. 3, p. 459-480.

Stewart, D.J., Yin, Z.Y., Bullard, S.M., \& MacLachlan, J.T. (2004), "Assessing the spatial structure of urban and population growth in the Greater Cairo area, Egypt: a GIS and imagery analysis approach", Urban studies, vol. 41, no. 1, p. 95-116.

Sutton, K. and Fahmi, W. (2001), "Cairo's urban growth and strategic master plans in the light of Egypt's 1996 population census results", Cities, vol. 18, no. 3, p. 135-149.

Tajbakhsh, K. (2003), Municipal Management and Decentralization Study: IRAN, World Bank, Regional Municipal Management and Decentralization Project.

Taubenböck, H., Wegmannb, M., Rotha, A., Mehl, H. and Dech, S. (2009), "Analysis of urban sprawl at mega city Cairo, Egypt using multisensoral remote sensing data, landscape metrics and gradient analysis", paper presented at International Symposium on Remote Sensing of Environment (ISRSE).

The World Bank (2016), Urban population (\% of total).

Tilaki,, M.J.M., Abdullah,, A., Bahauddin, A. and Marzbali, M.H. (2013), "The Influence of Landuse Planning on the Making of the Cities Physical Identity in Iran: An Analytical Review and Commentary", Middle-East Journal of Scientific Research, vol. 14, no. 6, p. 762-772.

UN-Habitat (2008), State of the World's Cities 2008-2009: Harmonious Cities, UNHabitat.

Yaftian, M. (2008), "The reasons behind the housing crisis in Iran", Donya-eEqtesad.

Zanganeh Shahraki, S. and Hosseini, S.M. (2009), "Evaluation of the role of urban management institution of Iran after the Islamic revolution in physical development of cities", Shahrdariha Magazine, vol. 9, no. 92, p. 26-31.

Zanganeh Shahraki, S., Sauri, D., Serra, P., Modugno, S., Seifolddini, F. and Pourahmad, A. (2011), "Urban sprawl pattern and land-use change detection in Yazd, Iran", Habitat International, vol. 35, no. 4, p. 521-528.

Zanjani, H. and Rahmani, M. (1989), Demographical statistics on Iranian cities: 1965-1991, Vezarate maskan va shahr sazi [Iranian Centre for Urban Studies and Architecture, Housing Ministry Press.

Ziari, K. (2006), "The planning and functioning of new towns in Iran", Cities, vol. 23 , no. 6 , p. $412-422$.

Zohry, A. (2002), Rural-to-urban labor migration: a study of upper Egyptian laborers in Cairo, University of Sussex.

Zohry, A. (2009), "The Development Impact of Internal Migration. Findings from Egypt", paper presented at the international Union for the Scientific Study of Population, XXVI IUSSP International Population Conference, Marrakesh. 